\title{
Pre-service Language Teachers' Reflections and Initial Experiences on the Use of Textbooks in Classroom Practice
}

\author{
Minna Maijala \\ School of Languages and Translation Studies, University of Turku, Finland
}

\begin{abstract}
In foreign language (FL) teaching and learning, textbooks provide the major source for both teachers and learners (see e.g., Guerrettaz \& Johnston, 2013; Richards, 2014). Although the use of textbooks and other teaching materials is one of the factors that makes the difference between novice and experienced teachers (see e.g., Savova, 2009), too little attention is paid to their use in teacher training programmes (see e.g., Canniveng \& Martinez, 2003). Based on research literature and empirical data derived from a questionnaire $(N=51)$ and interviews $(N=12)$ among FL teacher trainees during the one-year teacher training programme at a Finnish university, the following questions are addressed: What are pre-service language teachers' reflections on FL textbooks and their use? What kinds of experiences teacher trainees had with FL textbooks during the one-year teacher education programme? The results of this study give us more information on how language teacher trainees learn to use textbooks and other teaching materials. For instance, it emerged from the findings that the trainees were willing to create learner-centred teaching materials. In addition, the study can give ideas of how to develop courses for FL teacher education in order to pay more attention to a more independent use of textbooks and other teaching materials.
\end{abstract}

Index Terms - foreign language learning, language teacher education, foreign language teaching materials

\section{INTRODUCTION}

Despite the central role of textbooks in foreign language (FL) teaching and learning (see e.g., Guerrettaz \& Johnston, 2013; Richards, 2014), there is surprisingly little help in the research literature or guide books for teachers or teacher trainees on how to use them in practice (Tomlinson, 2012, p. 151). In general, too little attention is paid to the use of teaching materials in teacher training programmes (see e.g., Canniveng \& Martinez, 2003, 482; Augusto-Navarro, de Oliveira \& de Abreu-e-Lima, 2014). The reason for this might be related to the fact that textbooks and other teaching materials have not in general received much attention in the SL/FL research field (Tomlinson, 2012; Augusto-Navarro, de Oliveira \& de Abreu-e-Lima, 2014). In addition, teacher educators can sometimes have a negative image of textbooks (see e.g., Loewenberg-Ball \& Feiman-Nemser, 1988). But in FL teacher education programmes, the use of textbooks and other teaching materials is an important topic for at least two reasons. Firstly, textbooks are a constant companion and resource for both novice and experienced FL teachers. They provide help especially for novice teachers and teachers who lack confidence in using the target language in the classroom (Masuhara \& Tomlinson, 2008). Secondly, textbooks act as teacher developers or, as stated by Hutchinson and Torres (1994), as agents of change. For teacher educators, the question is how to teach the use of teaching materials. Prospective teachers should learn to select the 'right' materials for their learners, to adapt, and to reflect on the content of FL textbooks. In addition, they should understand that textbooks have a great influence on exams and vice versa (see e.g., Bailey, 1999).

Against this background, the aim of this study is to give an insight into reflections and initial experiences of preservice FL teachers in using textbooks and other teaching materials during a one-year teacher education programme at a Finnish university. Firstly, previous studies on the use of textbooks by in-service and pre-service language teachers are examined. Secondly, the collected questionnaire $(\mathrm{N}=51)$ and interview data $(\mathrm{N}=12)$ are analysed in order to capture first experiences of Finnish pre-service language teachers on the use of textbooks in classroom practice. Finally, the results of this study are discussed in order to give ideas on how to develop courses for FL teacher education in which more attention is paid to the use of textbooks and other teaching materials.

\section{Previous Studies on the Use of Textbooks by Pre-Service Language Teachers}

The extensive search by Tomlinson and Masuhara (2010) in their review article yielded that there are not many empirical studies available on language teachers' practice with textbooks. However, during the last few years some studies have shown ways of how FL teachers adapt and supplement textbooks in order to tailor their content to the learner group and learning context in question (see e.g., Grammatosi \& Harwood, 2013). Hence, the question of how to use textbooks effectively in order to maintain students' interest is important. McGrath (2006) studied teachers' and learners' images of English-language coursebooks from the metaphors that they had used in describing them. Both 
teachers and learners mostly held the coursebook as a guide. Teachers tended to have more positive images for coursebooks than learners. In the Japanese context, Rowland and Barrs (2013) studied the responses of 57 university students to the replacement of teacher-led lessons with small group, role-based textbook work in a yearlong English course focusing on reading skills. They concluded that teachers could restructure the classroom dynamics of textbook use by reworking the roles in a classroom. Even small changes in the classroom dynamics, as work in pairs or groups, made the work with textbooks more learner-centred. Hence, the use of textbooks matters.

Several studies indicate that the use of the textbook is one of the factors that make a difference between novice and experienced teachers. Hutchinson (1996, cited in Harwood, 2013, p. 12) found that lack of content knowledge emerged as a factor that had an influence on a novice teacher's patterns of textbook use. More experienced and much better qualified teachers used the textbook more flexibly than novice teachers and were able to adapt it to meet the learners' needs (similar results were obtained by Savova, 2009). Shawer's (2010) study on classroom-level curriculum development by EFL teachers revealed the link between textbook use and professional development. For instance, teachers who adapted or created their own materials had reportedly acquired a range of new pedagogical skills at the same time. The study by Edwards and Burns (2016) showed the potential of action research in supporting teachers' materials development and subsequent increase in learner motivation. In action research, an on-going process of reflection is needed (see e.g., Banegas, Pavese, Velázquez \& Vélez, 2013), which in turn is beneficial for the materials development.

There is not much research literature available on how pre-service or novice language teachers experience the use of textbooks and other teaching materials. However, there are studies showing that novice teachers had difficulties in using and adapting textbooks to meet the needs of the learners (Loewenberg-Ball \& Feiman-Nemser, 1988). For instance, they are not able to predict if textbook activities are well designed and suitable for the learner group in question (Tsui, 2003, Ch. 8). For novice teachers the textbook may provide assistance in how to come to terms with students' level and their prior knowledge (Crawford, 2002; McGrath, 2013, Ch. 2). Novice teachers may have difficulties in getting an overview of materials, how difficult it would be to teach and whether the textbook should be supplemented by teachermade materials (Richards, 2014). They also seem to have mostly negative images of teachers who just follow the book (Loewenberg-Ball \& Feiman-Nemser, 1988; Johnson, 1994). The results of the study by Maijala (2018) indicate that FL teacher trainees need to practice how to build a cultural framework for the texts and activities in the textbooks. Therefore, in language teacher education, trainees should be advised on how to become "better consumers of textbooks" (Hutchinson \& Torres, 1994, p. 327; see also McGrath, 2006). Otherwise, as Costa Afonso (2011) states, FL teachers may easily follow the content of the textbook automatically, without reflecting on it. Reflection is also needed when novice teachers learn how to investigate their learners' feelings towards coursebooks (McGrath, 2006).

Numrich (1996) analysed diaries kept by 26 novice English teachers during a practicum and revealed early worries concerning initial teaching experiences. The need for guidance in the use of textbooks was one of these. The study by Loewenberg-Ball and Cohen (1996) displayed that 75 to 85 percent of teacher trainees used a textbook when planning lessons. However, as stated above, the use of coursebooks has not necessarily been internalised in FL teacher education programmes (cf. McGrath, 2013, Ch. 2). Not only the use of the textbooks, but the development of supplementary materials and teachers' own materials, should also be incorporated in teacher training programmes. Bouckaert (2016) presented a course in materials development at a teacher education institute in the Netherlands. Based on a small-scale questionnaire among 10 student teachers, she suggested recommendations beneficial for language teacher education. According to these, teacher trainees should be given background reading materials dealing with theoretical perspective on materials development and design. They should also have an opportunity to conduct a small-scale research project during the course, and use ICT tools and applications.

\section{RESEARCH PROJECT}

\section{A. Context of the Study and Research Questions}

In the Finnish context, FL students apply for the pedagogical studies at the Department of Teacher Education usually after receiving their bachelor's degree in their major subject at the university subject department. During the one-year teacher education programme at the Department of Teacher Education and Teacher Training School associated with the Faculty of Education, the pedagogical skills are learned. In Teacher Training Schools, trainees are supervised by mentoring teachers with experience. The amount of lessons held by trainees at the Teacher Training School usually varies from 15 to 30 . At this particular university, the way in which trainees became familiar with different FL textbooks during the pedagogical studies depended very much on their mentors at the Teacher Training School and teacher educators at the Department of Teacher Education. In the context of the university in the focus of this study, the number of FL teacher trainees accepted per year varies between 50 and 70.

Finland is an interesting case in the textbook use, since studies have revealed a high use of them in Finnish FL classrooms. Harjanne, Larenas and Tella (2017) studied Finnish FL teachers' perceptions of teaching and study realities in their classrooms. The data was collected from 147 Finnish teachers through an online survey. The results showed that Finnish FL teachers use textbook a lot. They also seemed to be satisfied with the textbooks and valued especially the communicative oral activities. In Finland, there is a strong tradition of producing textbooks for the national school 
market. The textbook writers are mostly experienced non-native and native language teachers, not university academics. Finnish FL textbooks can be regarded as pedagogically oriented books that guide their users to notice or train specific language features (see e.g., Maijala \& Tammenga-Helmantel, 2019).

The overall goal of this study is to examine pre-service FL teachers and their reported conceptions and first practices in the use of textbooks and other teaching materials during the one-year teacher education programme at a Finnish university. The following research questions are addressed: 1. What are pre-service language teachers' reflections on FL textbooks and their use? 2. What kinds of experiences teacher trainees had with FL textbooks during the one-year teacher education programme?

\section{B. Participants, Data Collection and Methods}

This qualitative study was conducted at a Finnish university among 74 pre-service FL teachers during consecutive one-year teacher education programmes (see Table 1). The programmes started, respectively, in September and ended in May.

TABLE I

PROFILE OF PARTICIPANTS

\begin{tabular}{|l|l|l|l|l|l|l|}
\hline \multicolumn{1}{|c|}{ Participants } & Age & Gender & $\begin{array}{l}\text { Major languages of the } \\
\text { participants }\end{array}$ & $\begin{array}{l}\text { Previous } \\
\text { experiences } \\
\text { as a FL } \\
\text { teacher }\end{array}$ & $\begin{array}{l}\text { The amount of teaching } \\
\text { concerning FL textbook at the } \\
\text { Department of Teacher } \\
\text { Education }\end{array}$ & $\begin{array}{l}\text { The amount of lessons } \\
\text { held the Teacher } \\
\text { Training School }\end{array}$ \\
\hline $\begin{array}{l}\text { Questionnaire } \\
\text { December 2014 } \\
(\mathrm{N}=51)\end{array}$ & $22-57$ & $\begin{array}{l}43 \text { Female } \\
8 \text { Male } \\
\text { other }\end{array}$ & $\begin{array}{l}\text { English 18; German 11; } \\
\text { Swedish 10; Spanish 6; } \\
\text { Russian 2, Italian 2, } \\
\text { French 1 }\end{array}$ & $\begin{array}{l}\text { yes 10 } \\
\text { no 41 }\end{array}$ & $\begin{array}{l}\text { General lecture (2h) about the } \\
\text { theory of FL textbooks }\end{array}$ & $0-15$ hours \\
$\begin{array}{l}\text { Interviews May } \\
(\mathrm{N}=12)\end{array}$ & $22-35$ & 12 Female & $\begin{array}{l}\text { Swedish 6; French 3; } \\
\text { Spanish 2; German 1 }\end{array}$ & $\begin{array}{l}\text { yes 1 } \\
\text { no 11 }\end{array}$ & $\begin{array}{l}\text { General lecture (2h) about the } \\
\text { theory of FL textbooks; small- } \\
\text { scale textbook analysis as } \\
\text { homework and basis of group } \\
\text { discussions on the use of FL } \\
\text { textbooks (4 h) }\end{array}$ \\
\hline
\end{tabular}

During a lecture in the first half of the one-year teacher education programme, the questionnaire was anonymously completed by all the 51 students who attended. In the questionnaire, their conceptions of using teaching materials and reported their first experiences with textbooks were elicited. All trainees that completed the questionnaire had had a general lecture on the theory of FL textbooks. Their experiences with the textbooks before answering the questionnaire were very limited, because the study was conducted in the middle of the programme in December 2014. Only 10 trainees had previous experiences as a teacher, varying mostly from a couple of weeks to few months. However, most of them had been following lessons at the Teacher Training School and some of them had already taught a few lessons. The small number of male students in the study reflects the small proportion of them among language teacher trainees. Because it was possible to identify the male students, the gender of the students was omitted in quoting the responses.

The questionnaire data includes the basic information and responses of 51 pre-service language teachers to the following open questions in Finnish: 1. What kind of experiences do you have in the use of textbooks in FL teaching? Give examples of success and failure. 2. In your opinion, what is the role of teaching materials like in FL teaching? 3. What is an ideal FL textbook like? You can list the most important criteria. 4. How do you see the future of FL textbooks? 5. Extra. Further comments on textbooks and other teaching materials. The data was collected in the Finnish language, because it was important that participants fully understand the questions and could answer in detail.

The data from the questionnaire was supplemented through 12 interviews (Students 1-12, from now on St. 1-12) conducted with another group of trainees at the end of the programme in May 2016. The interviewees had taught about 15-30 lessons at the Teacher Training School where they were able to use textbooks and other teaching materials in 'real-life' classrooms under the supervision of mentoring teachers. In the theoretical part of the education at the Department of Teacher Education, all interviewed trainees had participated in group discussions dealing with the following aspects: selection of course books and other teaching materials, use of the course book (lesson planning and adaptation) and materials evaluation. They had also conducted a small-scale textbook analysis (linguistic and cultural content) before group discussions (see Table 1).

The interviews were chosen to complement the data, because answers in questionnaires do not always allow in-depth exploration, especially when respondents' beliefs are examined (cf. Borg 2013, Ch. 2). The semi-structured interviews lasted on average for 30-35 minutes and were conducted face-to-face with the teacher educator at the end of the programme in May 2016. The interviews focused on the questions about 1) the role of teaching materials in FL teaching and in teacher education in general, 2) the experiences of the pre-service teachers in the use of textbooks and other teaching materials during the programme, 3) their opinion on a good textbook and textbook activities, 4) their experiences in teaching grammar with the help of the textbooks, and 5) the 'ideal' textbook and the future of textbooks in FL teaching and learning. The interviews were recorded and transcribed in the original language Finnish.

Using qualitative methods commonly used in studies dealing with teacher learning, the data were categorised and analysed in order to identify most recurrent topics. In order to avoid predetermining the results, a grounded approach 
was chosen in order to allow topics to emerge both from the questionnaire and interview data (see e.g., Strauss \& Corbin, 1990). The qualitative analysis of the data was conducted in the original language of the respondents. The selected quotations in Finnish language were translated into English by the author. The double role of teacher educator as a researcher in this study can be regarded as both a limitation and an asset. On the one hand, due to the instructorstudent relationship, trainees might have avoided telling about the problematic issues. On the other hand, the study sheds light on the importance of a teacher educator and mentoring teachers in the development process of trainees. The practices described below refer only to this one particular university, which should also be noted as a limitation. Our aim was not to generalise the findings (cf. Burns, 1999, Ch. 2), but to report and to reflect on the experiences of the trainees in the use of the textbooks. In Section 4, results of the study are partially quantified, categorised and illustrated by using examples from the data. The number of respondents who mentioned the topic are given in brackets.

\section{FINDINGS}

\section{A. Questionnaire Results}

In the questionnaire, 33 of 51 respondents rated the textbook as important in FL teaching and learning. Trainees rated the textbook as necessary (10), a motivator (10), the basis of teaching (10), an overall package (5), and a guide (5). In addition, some of them stated that teachers use textbook a lot (3) and it is difficult to teach without it (5). One trainee of German commented that because she was as an unexperienced teacher and not able to design any material herself, she found support in the textbook. Teaching without a textbook was held time-consuming by seven trainees. Teaching with a textbook was often rated negatively, with attributes traditional (8), monotonous (7), easy (3), hindered creativity (2), passive (1) and binding teachers and learners to certain patterns (1). Creativeness was often connected to teaching without textbook. In general, trainees considered the production of supplementary materials as creative and rewarding and as a way of giving their teaching a personal touch.

22 of the 51 respondents reported about first experiences with textbooks and other teaching materials and gave examples of success and failure. Compared to trainees of other languages, who also brought up negative points, trainees of English seemed to have made more positive experiences with textbooks as the following excerpt from the questionnaire shows:

"During the training period in the autumn I taught a 9th class in the basic education that used a textbook named [...]. All materials including audios, workbooks with a key, teachers' guide, extra activities etc. were easily available in the internet, which made lesson planning and implementation easier. On the other hand, I was thinking, was is too easy? I taught in an international school as well, in which textbooks were not used. The lesson planning was time-consuming, but at the same time rewarding." (Teacher trainee of English)

The trainee felt that teaching with textbooks was made too easy. When giving examples of success and failure, 12 of 51 trainees named their favourite textbook, as the trainee in the example above. For liking a certain textbook, the most often mentioned reason was a well-designed electronic platform (8). 21 of 51 respondents told that they had already in the first half of the programme had a chance to produce supplementary materials to textbooks. They brought up plays and electronic materials that they had made for their lessons, for instance, Quizlet, Kahoot, YouTube clips and exercises on Smart Board. After having produced supplementary materials for lessons, trainees often had noticed how timeconsuming the production actually is, as the following excerpt from the questionnaire illustrates:

"In my opinion, teaching materials are very important. I noticed this, when already at the beginning

of the programme I had to make materials for a lesson of a class where books were not used."

(Teacher trainee of English)

Many trainees regarded ready-made textbooks as a time saver. At the same time, the willingness to create own teaching materials was often mentioned by respondents.

\section{B. Reflections on Experiences in the Interviews}

In the interviews conducted at the end of the one-year teacher education programme, trainees were able to reflect indepth on the role of textbooks in FL teaching and learning and their first experiences in using textbooks. They told about their observations on the role and use of textbooks in FL classrooms, where they had been teaching and observing other teacher trainees or mentors teach. Besides the role of the textbook, they were asked which textbook activities learners seemed to like the most and which activities they themselves liked the most. Table 2 presents the summary of trainees' reflections on the role of textbooks and their experiences of textbook activities. 
TABLE II

\begin{tabular}{|c|c|c|c|}
\hline Interviewee & $\begin{array}{l}\text { The role of the textbook in the } \\
\text { classroom }\end{array}$ & Textbook activities liked by learners & $\begin{array}{l}\text { Textbook activities liked by the } \\
\text { trainee }\end{array}$ \\
\hline St. 1 (Swedish) & $\begin{array}{l}\text { Observed heavy textbook use in the } \\
\text { teacher education }\end{array}$ & Questions to videos & Searching information \\
\hline St. 2 (German) & $\begin{array}{l}\text { Stated that the amount how much } \\
\text { textbooks are used depends on the } \\
\text { level of learners }\end{array}$ & $\begin{array}{l}\text { Reading/listening comprehension } \\
\text { exercises where students can work } \\
\text { on their own; Blank-filling exercises }\end{array}$ & $\begin{array}{l}\text { Questions to YouTube videos; } \\
\text { Oral exercises }\end{array}$ \\
\hline St. 3 (Swedish) & $\begin{array}{l}\text { Observed a dominant role; Held } \\
\text { textbook as a framework for } \\
\text { teaching and teachers' guide }\end{array}$ & $\begin{array}{l}\text { Learners like working in pairs; } \\
\text { Exercises in which they can produce } \\
\text { language }\end{array}$ & $\begin{array}{l}\text { Exercises in which students can } \\
\text { work together }\end{array}$ \\
\hline St. 4 (Spanish) & $\begin{array}{l}\text { Observed that the textbook is often } \\
\text { followed in FL classrooms; } \\
\text { Textbook control and support }\end{array}$ & Oral exercises & $\begin{array}{l}\text { Work in pairs; Models on how to } \\
\text { discuss with peers }\end{array}$ \\
\hline St. 5 (French) & $\begin{array}{l}\text { Observed that teaching is based on } \\
\text { the book }\end{array}$ & $\begin{array}{l}\text { Blank-filling exercises; Exercises in } \\
\text { which students can work } \\
\text { themselves. }\end{array}$ & $\begin{array}{l}\text { Motivating exercises in which } \\
\text { learners know why they do it }\end{array}$ \\
\hline St. 6 (Swedish) & $\begin{array}{l}\text { Observed that textbooks dominate } \\
\text { teaching }\end{array}$ & Games; Funny exercises & $\begin{array}{l}\text { Authentic texts about real-life } \\
\text { persons }\end{array}$ \\
\hline St. 7 (Swedish) & $\begin{array}{l}\text { Observed that teaching is based on } \\
\text { the book }\end{array}$ & $\begin{array}{l}\text { Oral exercises in which learners can } \\
\text { produce language }\end{array}$ & Oral exercises \\
\hline St. 8 (Swedish) & $\begin{array}{l}\text { Observed that teaching is based on } \\
\text { the book }\end{array}$ & $\begin{array}{l}\text { Exercises in which learners can } \\
\text { guess and deduce and do not need to } \\
\text { know everything. }\end{array}$ & $\begin{array}{l}\text { Suites many occasions and } \\
\text { different learners and is easy to } \\
\text { adapt }\end{array}$ \\
\hline St. 9 (French) & $\begin{array}{l}\text { Observed a dominant role } \\
\text { depending on the group }\end{array}$ & $\begin{array}{l}\text { Activating exercises in which } \\
\text { learners can produce language }\end{array}$ & $\begin{array}{l}\text { Learners like traditional } \\
\text { exercises }\end{array}$ \\
\hline St. 10 (French) & $\begin{array}{l}\text { Observed that teaching is based on } \\
\text { the book depending on the language } \\
\text { in question }\end{array}$ & $\begin{array}{l}\text { Exercises that tap into students' } \\
\text { interests }\end{array}$ & Work in pairs; Simulations \\
\hline $\begin{array}{l}\text { St. } 11 \\
\text { (Spanish) }\end{array}$ & $\begin{array}{l}\text { Observed a dominant role; Held } \\
\text { textbook as a tool and support for } \\
\text { teaching. }\end{array}$ & $\begin{array}{l}\text { Versatile exercises that activate } \\
\text { students }\end{array}$ & Translation exercises \\
\hline $\begin{array}{l}\text { St. } 12 \\
\text { (Swedish) }\end{array}$ & $\begin{array}{l}\text { Observed a dominant role, } \\
\text { especially in higher levels }\end{array}$ & Dialogues & Blank-filling exercises \\
\hline
\end{tabular}

When observing lessons at the Teacher Training School, trainees noticed the dominance of textbooks in classrooms. To alleviate this, some interviewees (St. 2, 10, 12) pointed out that the heavy textbook use depended on the level of learners. In the interviews, it could be observed that trainees had tried to move away from the traditional exercises, but often felt obliged to use the textbook as the following excerpts from interviews illustrate:

"Most of the mentoring teachers told us, what should be learned from textbooks. That is why textbooks played such an important role during the teacher education programme. During the longest training period, I could use the textbook more freely and I was able to put such exercises into practice in which students could search for information. We really used textbook a lot during the teacher education programme". (St. 1, Swedish)

"But when I think back over that teaching period, I remember that my both mentoring teachers told me clearly which units or activities should be treated in lessons. So in that way the textbook influenced my lessons even if I did not use it all the time." (St. 11, Spanish)

It emerged that trainees felt that they were expected to use textbooks the way mentoring teachers suggested. Thus, they often thought that the role that mentoring teachers played in the use of textbooks was too big.

In general, trainees found those textbook activities beneficial that enabled language learners practice the language with peers. In particular, they stressed the importance of oral activities. Nevertheless, trainees felt that their students liked blank-filling exercises in particular because it was easy to choose between right and wrong (St. 2, 5). One interviewee reflected on how she had thematised blank-filling exercises in her lesson:

"Students say that they like blank-fillings, but after you have talked with them and asked them, if they learned anything from this, they start to reflect that perhaps I did not learn so much, although it is fun to fill in the gaps. [---] But nothing sticks in mind anyway. I have told my students that when you are in Germany, it is not about filling in blanks, but using the language in real. (St. 2, German)

In the interviews, trainees were asked to reflect on their experiences on the use of textbooks during the teacher education programme and give examples of success and failure. Their experiences are summarised in Table 3 . The most dominant themes were: i) textbook as a structure tool, pattern or framework for teaching (cf. Crawford, 2002; see also Loewenberg-Ball \& Feiman-Nemser, 1988), and ii) textbook as a supporter (cf. McGrath, 2013, p. 86) or as a kind of teacher or mentor for trainees. In addition, iii) the influence of the trainees' own school experiences on the use of textbooks as a teacher could be observed.

Textbook as a structure tool. In general, most interviewees acknowledged that they need textbooks in order to understand the curricular development. On the other hand, they felt that their teaching was schematic and not creative when they followed the textbook (St. 8). However, they often mentioned that textbooks helped when they did not know 
in which order they should progress, which activities were well designed and suitable for their group of learners (cf. Tsui, 2002, p. 213). Trainees often found the design of activities difficult. Particularly, their problems lied in adapting textbook activities to meet the needs and the level of their students. The structure of textbooks was found helpful when planning lessons at the Teacher Training School. It seemed to be difficult for trainees not to follow the textbook:

TABLE III

OVERVIEW OF TRAINEES' INITIAL TEACHING EXPERIENCES WITH TEXTBOOKS

\begin{tabular}{|c|c|c|c|}
\hline Interviewee & $\begin{array}{l}\text { Grammar teaching with } \\
\text { textbooks }\end{array}$ & Adaption of textbooks & $\begin{array}{l}\text { Teaching experiences with textbooks } \\
\text { (excerpts) }\end{array}$ \\
\hline St. 1 (Swedish) & Modified grammar & $\begin{array}{l}\text { Taught culture parts in an own } \\
\text { way }\end{array}$ & $\begin{array}{l}\text { The use of textbook is very schematic. [---] I } \\
\text { would have liked to have more guidance on } \\
\text { how to make it more interesting for students. }\end{array}$ \\
\hline St. 2 (German) & $\begin{array}{l}\text { Modified textbook } \\
\text { activities }\end{array}$ & $\begin{array}{l}\text { Created quizzes and games on } \\
\text { the basis of the textbook }\end{array}$ & $\begin{array}{l}\text { Students liked blanks-filling exercises: I told } \\
\text { them that when they are in Germany they are } \\
\text { no blanks to fill in. So you have to really use } \\
\text { the language. [---] }\end{array}$ \\
\hline St. 3 (Swedish) & $\begin{array}{l}\text { Made own presentations } \\
\text { based on the textbook }\end{array}$ & $\begin{array}{l}\text { Taught culture parts in an own } \\
\text { way }\end{array}$ & $\begin{array}{l}\text { I feel obliged to follow the textbook. [---] I } \\
\text { have to do all exercises in the book, because } \\
\text { they are there. [---] It is easy to use them. }\end{array}$ \\
\hline St. 4 (Spanish) & $\begin{array}{l}\text { Did not teach grammar } \\
\text { directly from the book. }\end{array}$ & $\begin{array}{l}\text { Made own grammar exercises } \\
\text { based on the book }\end{array}$ & $\begin{array}{l}\text { First, the presentation of grammar in a } \\
\text { teacher-centred way, then work in pairs. [---] }\end{array}$ \\
\hline St. 5 (French) & $\begin{array}{l}\text { Found grammar exercises } \\
\text { in textbooks mechanical }\end{array}$ & Made own questions to the texts & $\begin{array}{l}\text { It was easy to use textbooks, because I have } \\
\text { learned languages myself. [---] It was difficult } \\
\text { to find suitable exercises for learners. }\end{array}$ \\
\hline St. 6 (Swedish) & $\begin{array}{l}\text { Found clear presentations } \\
\text { of grammar rules useful } \\
\text { and they helped to teach }\end{array}$ & $\begin{array}{l}\text { Added something to the } \\
\text { exercises, for instance, oral } \\
\text { parts }\end{array}$ & $\begin{array}{l}\text { It is a challenge that there is so much material } \\
\text { in the book. [---] It is difficult to find the most } \\
\text { important exercises. }\end{array}$ \\
\hline St. 7 (Swedish) & $\begin{array}{l}\text { Tried to present grammar } \\
\text { in an own way }\end{array}$ & $\begin{array}{l}\text { Transformed oral exercises into } \\
\text { written ones or vice versa }\end{array}$ & $\begin{array}{l}{[---] \text { Electronic teacher's manual helped me to }} \\
\text { teach. [---] Textbook kept the lesson going. } \\
{[---]}\end{array}$ \\
\hline St. 8 (Swedish) & $\begin{array}{l}\text { Taught grammar always } \\
\text { from the book, found rap } \\
\text { songs funny }\end{array}$ & $\begin{array}{l}\text { Combined exercises or } \\
\text { transformed oral exercises into } \\
\text { written ones or vice versa }\end{array}$ & $\begin{array}{l}\text { I would have wanted to use the book less in } \\
\text { lessons in upper secondary school [fi. lukio]. } \\
\text { In the junior high school [grades 7-9] were } \\
\text { much nicer in the textbook, so it was nicer to } \\
\text { use. The book in the upper secondary school } \\
\text { was old fashioned, and how to say, pretty dull. } \\
\text { So I did not like to use it. [---] }\end{array}$ \\
\hline St. 9 (French) & $\begin{array}{l}\text { Found that the grammar in } \\
\text { the global book was hidden } \\
\text { to the texts and it was } \\
\text { teachers' job to teach it }\end{array}$ & $\begin{array}{l}\text { Transformed oral exercises into } \\
\text { written ones or vice versa }\end{array}$ & $\begin{array}{l}\text { It was difficult to find suitable exercises for } \\
\text { learners. [---] In the fourth class, a global } \\
\text { textbook was used. I did not like it at all. But } \\
\text { it was also a kind of funny because there was } \\
\text { a lot of pictures in it and very little text. [---] } \\
\text { So as a teacher I was able to adapt it. [---] }\end{array}$ \\
\hline St. 10 (French) & $\begin{array}{l}\text { Found teaching easy with } \\
\text { Finnish books }\end{array}$ & $\begin{array}{l}\text { Used own exercises instead of } \\
\text { ones from the textbook }\end{array}$ & $\begin{array}{l}\text { [---] I would say that Finnish textbook are } \\
\text { very good. When I used a global textbook, it } \\
\text { was really poor for both learners and the } \\
\text { teacher. When you plan your lessons you are } \\
\text { so used to the Finnish books that are very } \\
\text { clear. Global books are not. They express } \\
\text { things differently and there are diffenent kinds } \\
\text { of activities. I can't follow them. }\end{array}$ \\
\hline $\begin{array}{l}\text { St. } 11 \\
\text { (Spanish) }\end{array}$ & $\begin{array}{l}\text { Found that grammar did } \\
\text { not suit the group of } \\
\text { students in question; } \\
\text { modified the grammar in } \\
\text { the book }\end{array}$ & $\begin{array}{l}\text { Sequences of grammar } \\
\text { presentation; Gave more } \\
\text { examples }\end{array}$ & $\begin{array}{l}\text { First, I had feelings of oppression because I } \\
\text { thought I would be expected to follow the } \\
\text { book. [---] }\end{array}$ \\
\hline $\begin{array}{l}\text { St. } 12 \\
\text { (Swedish) }\end{array}$ & $\begin{array}{l}\text { Learned the grammar from } \\
\text { the textbook; Difficult to } \\
\text { find ways how students } \\
\text { could work with grammar }\end{array}$ & $\begin{array}{l}\text { Made cultural information more } \\
\text { topical }\end{array}$ & $\begin{array}{l}\text { It has taken so much time to get in to the } \\
\text { textbooks. [---] Teaching grammar has been } \\
\text { most difficult for me. }\end{array}$ \\
\hline
\end{tabular}

"I felt that I do not have the courage to depart from the textbook. I am not able to do anything else. I must do the exercises in the book, because they are there. I just cannot leave them out. (St. 3)

The dominant role of textbooks was often questioned, as the following comment shows:

[...] I could have easily done something else on the same topics. For instance, if we had food as a topic, I did not understand why I had to use the textbook. I could have used food blogs from the internet or something else. [---] (St. 8, Swedish)

Some trainees felt that it was difficult to find suitable texts and activities for the target group. It also took time to get used to the textbook. On the other hand, digital materials were found useful, but some trainees found it more difficult to find a close contact to students when they had to stand behind the computer desk.

Textbook as a mentor or teacher. In the interviews, trainees often mentioned that they had found help from textbooks, for instance, in finding out the right level of learners. Some interviewees pointed out that it is difficult to choose the 
relevant exercises "that support the learning process" (St. 5). In grammar teaching, in particular, the central role of the textbook as a teacher or guide could be observed. This came out when some trainees emphasised that it was important to learn the grammar oneself before teaching it with the textbook (St. 6). FL textbooks usually include an overwhelming amount of material and trainees reported difficulties in selecting the suitable combination for their learners. An example from an interview illustrates this:

"Normally you had to go through the activities as they are in the book, but when there is not time for this, you have to pick up the most relevant ones. For the mentoring teacher it is always easy to say that take this and that, they are the most important activities, but you are as a trainee very unsure.

I can easily pick up activities for fun, but [---].” (St. 6, Swedish)

In grammar teaching, experiences with textbooks were both negative and positive. In the interviews, it was often mentioned that teaching grammar with nationally used Finnish textbooks was regarded as 'easy' and 'safe'. For instance, St. 8 stated that students learned from the book and that the book was clearly structured. Trainees who had worked with global textbooks found their use difficult (St. 9, 10, see Table 3). One trainee pointed out that the textbook both helped and hindered grammar teaching:

"But if learners do not understand the grammar rule, it does not help at all if they just do the textbook exercises, because it is very mechanical. Especially if they do not understand the grammar rule." (St. 5, French)

In grammar teaching, trainees relied on the book, but were willing to present grammar in their own way. Seven interviewees mentioned that they had modified textbook grammar exercises and made efforts to teach grammar in their own way. It could be observed that they wanted to modify activities to make them learner-centred and interactive by transforming writing exercises into oral ones and vice versa (St. 7, 8, 9). The adaptation of textbooks by trainees usually meant supplementary PowerPoint slides to the textbook. As St. 3 stated "[...] culture parts I taught in my own way. I made own PowerPoint presentations and did not follow the content of the textbook."

The influence of trainees' own school experiences as a learner on the use of textbooks as a teacher. Some trainees stated that the use of textbooks was easy because they had their own experiences about it when they were students themselves. Trainees' own experiences on formal language learning in school seemed to guide the use of textbook during the programme (St. 5). St 12, who had learned the language informally, found teaching grammar difficult. She had to learn grammar rules from the textbook before teaching her classes.

\section{Discussion: OUTCOMES AND IMPLiCATIONS FOR LANGUAGE TEACHER EDUCATION}

The results of this study show the dominance of textbooks in the FL teacher education programme. Trainees often referred to the frequent textbook use in the Teacher Training school, where they had been observing teaching. This is in line with previous studies showing the heavy textbook use in Finnish FL classrooms (cf. Harjanne, Laranas \& Tella, 2017). The role of mentors in Teacher Training School was decisive in the use of textbooks, since trainees' experiences seemed to be dependent on their guidance. They were told how the textbook should be followed and which activities should be chosen. Trainees wanted to learn how to teach more independently, that is, they were not just following the book. They relied on the book, but were in most cases willing to present their content in their own personal way. Mentoring teachers who just followed the book were seen in a negative light (similar results were obtained by Johnson, 1994). Creativeness was often connected with teaching without a textbook. Trainees were eager to present grammar in their own way in order to give their teaching a personal touch. The results indicate that trainees would have needed more support from the mentoring teachers in using textbooks creatively. In sum, trainees seemed to be dependent and independent on textbooks at the same time.

The results of this study indicate that trainees had difficulties in adapting textbooks to meet the needs of the learners (cf. Loewenberg-Ball \& Feiman-Nemser, 1988). In addition, they had problems in getting an overview of the textbooks, and in finding ways of how to supplement them with teacher-made materials (cf. Richards, 2014). Since there will always be a need to adapt any already-published materials regardless of the type of situation in which a teacher finds herself (cf. Macalister, 2016), pre-service FL teachers should get a chance to try this in teacher education programme. Prior experiences from a formal language teaching in school had an influence on the use of textbooks by trainees.

There seemed to be a conflict between the learner-centered approach to teaching (derived from the pedagogical studies) versus the teacher-centered approach (derived from the observed practice in the teacher training school) (cf. Farrell, 2009). Some trainees wished that mentoring teachers could have encouraged them more often to use textbooks independently. In the interviews, they brought up that they had added content to textbooks and also changed the format of the activities, that is, transformed oral exercises to written ones or vice versa. In most cases, this transformation had taken place more from the initiative of the trainee and not as a result of encouragement by mentoring teachers. In general, trainees found useful in language classroom textbook activities that enabled learners to use the target language communicatively with peers. Hence, they had been trying how to make teacher-centred methods more learner-centred (cf. Kagan, 1992; Johnson, 1996; Numrich, 1996).

In general, most interviewees acknowledged that they need textbooks in order to understand the curricular development. Trainees found digital materials useful, but at the same time some of them felt that electronic devices tie the teacher in front of the class behind the computer desk and make the contact with students more difficult. Some 
trainees pointed out that teaching with Finnish textbooks is too easy and safe. Trainees who had worked with global textbooks, found their use very difficult compared to Finnish ones. This study showed differences between trainees of different languages. Trainees of English, in comparison with trainees of other languages, seemed to have more positive experiences with textbooks. Trainees of other languages also brought up negative points more often.

The results of this study show that trainees need to be guided on how to use textbooks in a pedagogically meaningful way and not just to follow them without reflection. Teachers need not only guidance on how to follow the textbook, but also how to adapt their content for their students as well as on how to produce supplementary materials. Teacher educators and mentoring teachers should make their tacit knowledge on the use of the textbook visible, for instance, by using the think aloud method. Teacher educators and mentoring teachers could help trainees to analyse textbooks, for instance, by conducting a small-scale analysis of teaching materials and then reflect on it with peers (cf. McGrath, 2013, pp. 207-208). For example, reflecting together with trainees on the selection of suitable exercises for the group of learners could also be beneficial. In general, teachers should be more involved in materials adaptation, e.g. by using methods of action research (Edwards \& Burns, 2016). Small-scale action research projects, in which trainees focus on their use of teaching materials in the classroom, could easily be conducted during the teacher education programme. In addition, this study showed that production of supplementary materials to the textbooks should be practiced. In the reflection afterwards, trainees could discuss on how the designed materials had worked in practice. Trainees should learn that teachers guide learning and not textbooks.

\section{CONCLUSION}

In this article, we have conducted a study that explored Finnish pre-service teachers' reflections and experiences in the use of textbooks during a one-year teacher education programme. The importance of the topic was justified by the fact that textbooks provide the major source in FL classroom. In addition, the use and adaption of textbooks and other teaching materials does not necessarily receive much attention in language teacher education. The data were collected with a questionnaire filled in by 51 Finnish pre-service FL teachers in 2014 and interviews of 12 trainees in 2016 during the one-year teacher education programme at a Finnish university. Based on our results, there is evidence to suggest that the use of textbooks is not in the focus of the teacher education programme, although Finnish FL teaching mostly relies on them. The study revealed the decisive role of mentors in the Teacher Training School, since they guided trainees and often chose activities from textbooks for them. The results indicate that trainees wanted to learn how to teach more independently, that is, they are not just following the book. In addition, the results showed that trainees had tried to adapt textbooks exercises in order to make them more learner-centred. They found such textbook activities useful in language classroom that enable learners to use the target language communicatively with peers. Regarding language teacher education, there is need for more studies that increase understanding of how language teachers learn from textbooks and how the use of textbooks could be practiced in teacher education programmes.

\section{ACKNOWLEDGEMENTS}

The author wishes to thank all students who participated in the study.

\section{REFERENCES}

[1] Augusto-Navarro, E. H., Luciana C. de Oliveira \& de Abreu-e-Lima, D. M. (2014). Teaching Pre-service EFL Teachers to Analyse and Adapt Published Materials: An Experience from Brazil. In S. Garton, \& K. Graves (eds.), International Perspectives on Materials in ELT. Basingstoke: Palgrave Macmillan UK, 237-252.

[2] Bailey, K. M. (1999). Washback in Language Testing. TOEFL Monograph Series MS 15. Princeton, New Jersey: Educational Testing Service.

[3] Banegas, D., Pavese, A., Velázquez, A., \& Vélez, S. M. (2013). Teacher professional development through collaborative action research: Impact on foreign English-language teaching and learning. Educational Action Research 21.2, 185-201.

[4] Borg, S. (2013). Teacher Research in Language Teaching. A critical analysis. Cambridge: Cambridge University Press.

[5] Bouckaert, M. (2016). Designing a materials development course for EFL student teachers: principles and pitfalls. Innovation in Language Learning and Teaching 10.2, 90-105.

[6] Burns, A. (1999). Collaborative action research for English language teachers. Cambridge: CUP.

[7] Canniveng, C., \& Martinez, M. (2003). Materials Development and Teacher Training. In B. Tomlinson (ed.), Developing Materials for Language Teaching. London: Continuum, 479-489.

[8] Costa Afonso, C. (2011). Intercultural Competence: A Major Issue in Foreign Language Teacher Training. In A. Witte, \& T. Harden, Theo (eds.), Intercultural Competence: Concepts, Challenges, Evaluations. Oxford, New York: Peter Lang, 127-140.

[9] Crawford, J. (2002). The role of materials in the language classroom: Finding the balance. In J. C. Richards, \& W. A. Renandya (eds.), Methodology in language teaching: An anthology of current practice. Cambridge: CUP, 80-91.

[10] Edwards, E. \& Burns, A. (2016). Action research to support teachers' classroom materials development. Innovation in Language Learning and Teaching 10.2, 106-120.

[11] Farrell, T. S. C. (2009). The Novice Teacher Experience. In A. Burns \& J. C. (Eds.), The Cambridge Guide to Second Language Teacher Education. Cambridge: CUP, 182-189. 
[12] Grammatosi, F., \& Harwood, N. (2013). An Experienced Teacher's Use of the Textbook on an Academic English Course: A Case Study. In N. Harwood (ed.), English Language Teaching Textbooks: Content, Consumption, Production. Basingstoke: Palgrave Macmillan UK, 178-204.

[13] Guerrettaz, A. M. \& Johnston, B. (2013). Materials in the classroom ecology. The Modern Language Journal 97.3, 779-796.

[14] Harjanne, P., Larenas, C. D., \& Tella, S. (2017). Foreign-language teaching and studying in Chilean and Finnish classrooms as seen by teachers. Journal of Language and Cultural Education 5.3, 1-21.

[15] Harwood, N. (2013). Content, consumption, and production: Three levels of textbook research. In Harwood, N. (ed.), English Language Teaching Textbooks: Content, Consumption, Production. Palgrave Macmillan UK, 1-41.

[16] Hutchinson, T., \& Torres, E. (1994). The textbook as agent of change. ELT Journal 48.4, 315-328.

[17] Johnson, K. E. (1994). The emerging beliefs and instructional practices of preservice English as a second language teachers. Teaching \& Teacher Education 10.4, 439-452.

[18] Kagan, D. M. (1992). Professional Growth among Preservice and Beginning Teachers. Review of Educational Research 62.2, 129-169.

[19] Loewenberg-Ball, D. \& Feiman-Nemser, S. (1998). Using textbooks and teachers' guides: A dilemma for beginning teachers and teacher educators. Curriculum Inquiry 18.4, 401-423.

[20] Macalister, J. (2016). Adapting and adopting materials. In M. Azarnoosh, M. Zeraatpishe, A. Faravani \& H. R. Kargozari (eds.), Issues in Materials Development. Rotterdam: Sense Publishers, 57-64.

[21] Maijala, M. (2018). Culture teaching methods in foreign language education: pre-service teachers' reported beliefs and practices. Innovation in Language Learning and Teaching, DOI: 10.1080/17501229.2018.1509981.

[22] Maijala, M. \& Tammenga-Helmantel, M. (2019). Grammar exercises in Dutch, Finnish and global textbooks for teaching German as a foreign language. The Language Learning Journal 47.5, 537-557.

[23] Masuhara, H. \& Tomlinson, B. (2008). Materials for General English. In B. Tomlinson (ed.), English language learning materials: A critical review. London, New York: Continuum, 17-37.

[24] McGrath, I. (2006). Teachers' and learners' images for coursebooks. ELT journal 60.2, 171-180.

[25] McGrath, I. (2013). Teaching Materials and the Roles of EFL/ESL Teachers. Practice and Theory. London etc.: Bloomsbury.

[26] Numrich, C. (1996). On Becoming a Language Teacher: Insights from Diary Studies. TESOL Quarterly 30.1, 131-153.

[27] Richards, J. C. (2014). The ELT Textbook. In S. Garton and K. Graves (eds.), International Perspectives on Materials in ELT. Basingstoke: Palgrave Macmillan UK, 19-36.

[28] Rowland, L. \& Barrs, K. (2013). Working with textbooks: reconceptualising student and teacher roles in the classroom. Innovation in Language Learning and Teaching 7.1, 57-71.

[29] Savova, L. (ed.) (2009). Using Textbooks Effectively. TESOL Classroom Practice Series. Teachers of English to Speakers of Other Languages. Alexandria, VA: TESOL.

[30] Shawer, S. F. (2010). Classroom-level curriculum development: EFL teachers as curriculum-developers, curriculum-makers and curriculum-transmitters. Teaching and teacher education 26.2, 173-184.

[31] Strauss, A. L. \& Corbin, J. (1990). Basics of qualitative research: Grounded theory procedures and techniques. Newbury Park, Calif.: Sage.

[32] Tomlinson, B. (2012). Materials development for foreign language learning and teaching. Language Teaching 45.2, 143-179.

[33] Tomlinson, B. \& Masuhara, H. (2010). Published research on materials development for language learning. In B. Tomlinson \& H. Masuhara (eds.), Research for materials development in language learning. London: Continuum, 1-18.

[34] Tsui, A. (2003). Expertise in teaching: Case studies of ESL teachers. New York: Cambridge University Press.

Minna Maijala, Ph.D. in German (2003), Ph.D. in Education (2010), is Associate Professor in Language Teaching and Learning at the School of Languages and Translation Studies, University of Turku, Finland. In 2004-2018, she has worked as a senior lecturer at the Language Centre, University of Turku and at the Department of Teacher Education, University of Turku. Her research interests are teaching and learning German as a foreign language, the cultural content in foreign language teaching, and foreign language teaching materials. 